welcomed his reoccupation of the large house), and he moved to Leningrad. He was able to make one or two visits to Western Europe (Bonn, Paris, and London) and to study with his Buriat Lama friends in Central-Asian monasteries. During the inter-war period the Russian sphere was, except for the Academy's Bicentenary in 1925, rather screened; but the work of scholars, heroically maintained, was partly known from publications which reached the outside world. Scherbatskoy's share included the most mature and massive of his writings, of which we can merely name his great Buddhist Logic (2 vols.), the editions of the Nyaya-bindu and its commentaries (Indices by Obermiller), of the Santānāntarasiddhi (Refutation of Solipsism, Tibetan version), and the Abhisamaya $\bar{a}-$ lamkiara (with Obermiller), and the most elaborately schemed edition and translation of the Abhidharma-kosia, with its versions (Chinese, Tibetan, etc.) and commentaries. These are largely concerned with the concluding third stage of Buddhist philosophy: the Abhidharma-kośa, however, belongs to the second stage, which is also represented by Scherbatskoy's The Conception of Buddhist Nirvana (1927): the first stage, exemplified by Pali Buddhism, was treated in the Society's own publication (1923) of " The Central Conception of Buddhism and the meaning of the word 'Dharma" ".

Scherbatskoy's giant physique towered in most companies ; his friendliness and good humour, his scholarly integrity and depth, and even his perfect command of English (as well as French and German) idiom and enunciation were shared by practically the whole fraternal band of St. Petersburg orientalists whose focus, during the early years of the present century, was the Academy's Asiatic Museum. His memory will be associated, as he would have wished, with the names of Radloff, Saleman, Oldenburg, von Stael-Holstein, Rosenberg, Alexeiev, and others of that com pany as well as with those of collaborators of a later date and pupils like Dr. E. E. Obermiller and Dr. Tubiansky.

\title{
Florence Ayscough MacNair
}

When Florence Ayscough (née Wheelock) arrived from Canada as a young bride in Shanghai, she was in her very early twenties; and she soon decided that, since her life was to be cast in China, she would learn to speak Chinese and to read Chinese literature. If every British bride in the Orient showed half this intelligent 
attitude, she would prove herself of far more use to her country and to humanity in general than she often does. Florence Ayscough came of intellectual Unitarian stock, had been educated in Boston, and to her an appreciative study of Chinese was a natural and pleasurable duty. Most of the years she spent in China she had a Chinese teacher reading beside her. The North China Branch of the Royal Asiatic Society in Shanghai was in low water, and for years she worked hard and successfully at its rehabilitation, spending her energies and her money freely as its Honorary Librarian. Chinese art also, with its beauty and colour, became her delight.

Her first book, Fir-Flower Tablets, was a translation of poems from the Chinese, done in collaboration with Amy Russell Lowell. Her next, $A$ Chinese Mirror, was a thoughtful analysis of the foundations of the Chinese social and governmental structure, with special regard to the symbolism of the imperial palaces of Peking. Soon, however, her love of the Chinese poets reasserted itself, and she published her translations of the poems of $T u F u$, together with a biography of that poet as deduced from the study of his works : and this was followed in 1934 by her Travels of a Chinese Poet. Her rendering of the ideographs was full of vivid imagery, and the modern archæologist with his more recent discoveries concerning the structure of the ideographs, might not always subscribe to her reading. But she did a great service to the public in America and England, by her enthusiastic introduction of so great a poet as $\mathrm{Tu} \mathrm{Fu}$, till then unknown to them. At the same time, when lecturing, she managed to convey something of the chanting tone and rhythm of spoken Chinese verse-no mean task. Other lighter books had much charm: The Autobiography of a Chinese Dog (her own Pekingese), and Fire-Cracker Land. Her last work, Chinese Women Yesterday and To-day, had as a theme the realization that the women leaders of the present time are but successors of a long line of capable, though secluded, Chinese women.

Of a gallant and warm personality, she welcomed and encouraged young writers. Speaking French and German fluently, she lectured before many learned societies, and had friends in every capital in Europe. In 1935 she married Professor Harley Farnsworth MacNair, the historian, and their Chicago home was a centre of hospitality, open to all from the Far East. To her bereaved husband our sympathy is extended.

Dorothea Hosie. 